\title{
Development and reproducibility of an instrument to assess behavioral and environmental aspects related to cyclist safety
}

\section{Desenvolvimento e reprodutibilidade de um instrumento para avaliar aspectos comportamentais e ambientais relacionados à segurança do ciclista}

\author{
Talita Chrystoval Truchym ${ }^{1,2}$ \\ (D) https://orcid.org/0000-0002-7797-4706 \\ Iazana Garcia Custódio ${ }^{1,2}$ \\ (D) https://orcid.org/0000-0002-8196-1692 \\ Adriano Akira Ferreira Hino $0^{1,3,4}$ \\ (D) https://orcid.org/0000-0003-1649-9419
}

\begin{abstract}
In urgency and emergency services, the bicycle is the second means of transportation more widely used by the victims at the time of the accident. However, aspects associated with major and minor accidents are poorly understood. The aim was to develop an instrument and test its reproducibility, in order to evaluate behavioral and environmental aspects related to cyclist safety. The instrument was based on footage taken through a camera attached to the cyclist helmet and from a review of literature. Take part in the study academics that used the bicycle for transportation at least once a week. Participants were instructed to indicate any safety-critical events on their way and situations of minor gravity based on the perception of real imminence of an accident. In order to identify aspects related to cyclist safety, the routes were divided in periods of 30 seconds. In order to test inter-rater reproducibility, two researchers received theoretical-practical training and performed the instrument in a sample of 100 periods. In order to evaluate the intra-rater reproducibility, one of the evaluators performed a second application after 07 days. The reproducibility of the categorical variables of the instrument were tested through general agreement and Kappa index. For the variables with continuous measuring range, the Intraclass Correlation Coefficient (ICC) was used. The percentage agreement varied between $88-100 \%$ and the Kappa values varied between $0.76-1.00$. The ICC values ranged from $0.96-0.99$. The developed instrument presents adequate reproducibility for use in research to evaluate the cyclist safety in urban contexts.
\end{abstract}

Key words: Accident prevention; Bicycling; Reproducibility of results; Traffic accidents.

Resumo - Em serviços de urgência e emergência a bicicleta éo segundo meio de locomoção mais utilizado pelas vitimas na hora do acidente. No entanto, os aspectos associados aos acidentes de maior e menor gravidade são pouco conhecidos. O objetivo deste trabalho foi desenvolver e testar a reprodutibilidade de um instrumento para avaliar aspectos comportamentais e ambientais relacionados à segurança de ciclistas. O instrumento foi baseado em filmagens realizadas através de câmera acoplada no capacete e a partir de revisão de literatura. Participaram do estudo universitários que utilizavam a bicicleta para deslocamento ao menos um dia por semana, foram orientados a indicar no trajeto eventos críticos, situações de menor gravidade baseadas na percep̧ção de iminência real de acidente. Para identificar os aspectos relacionados à segurança, os trajetos foram fracionados em periodos de 30 segundos. Para testar a reprodutibilidade interavaliador dois pesquisadores receberam treinamento teórico-prático e realizaram a aplicação do instrumento em uma mostra de 100 periodos. Para avaliar a reprodutibilidade intra-avaliador, um dos avaliadores realizou uma segunda aplicação após 07 dias. A reprodutibilidade das variáveis categóricas do instrumento foi testada através da concordância geral e indice Kappa. Para as variáveis com escala de medida contínua foi utilizado o coeficiente de correlação intraclasse. Os percentuais de concordância variaram entre 88 e 100\% e os valores de Kappa entre 0,76 e 1,00. Os valores de CCI variaram entre 0,96 0,99. O instrumento desenvolvido apresenta reprodutibilidade adequada para o emprego em pesquisas para avaliação da segurança de ciclistas em contextos urbanos.

Palavras-chave: Acidentes de trânsito; Ciclismo; Prevenção de acidentes; Reprodutibilidade dos testes.
1 Federal Technological University of Paraná. Postgraduate Program in Physical Education. Curitiba, PR. Brazil.

2 Federal Technological University of Paraná. Research Group on Environment, Physical Activity and Health. Curitiba, PR. Brazil.

3 Pontifícia Universidade Católica do Paraná. Polytechnic School - Graduate Program In in Health Technology. Curitiba, PR. Brazil.

4 Pontifícia Universidade Católica do Paraná. School of Life Sciences. Research Group on Physical Activity and Quality of Life. Curitiba, PR. Brazil.

Received: 13 June 2019 Accepted: 15 October 2019

How to cite this article Truchym TC, Custódio IG, Hino AAF. Development and reproducibility of an instrument to assess behavioral and environmental aspects related to cyclist safety. Rev Bras Cineantropom Desempenho Hum 2020, 22:e65714. DOl: http://dx.doi.org/10.1590/19800037.2020v22e65714

Copyright: This work is licensed under a Creative Commons Attribution 4.0 International License. 


\section{INTRODUCTION}

The external causes of morbidity and mortality situations related to accidents and violence constitute a public health problem in Brazil1 ${ }^{1,2}$. In 2016, deaths from these causes accounted for $11.9 \%$ of total deaths in the year ${ }^{3}$. Among external causes, transport accidents represent $24.5 \%$ and are the second most frequent cause of this type of accident ${ }^{3}$. In the year of 2016, 1,262 deaths were from cyclists ${ }^{3}$.

While the death of cyclists represents a small part of the total number of fatalities on road traffic accidents, the bicycle has been reported by the Brazilians' emergency and urgency services, in the country's capitals ${ }^{4}$, as the most often mode of transportation used at the time of accidents. In the city of São Paulo, from 2011 to 2013, the most prevalent characteristics among bicycle accidents were: male; age up to 24 years old; type of victim (pilot vs. pedestrian); period of the day from 07:00 A.M to 06:00 P.M; leg injury; immediate hospital discharge ${ }^{5}$ and use of the bicycle for transportation ${ }^{6}$. These data from "Sistema de Vigilância de Violência e Acidentes" (VIVA) show that: male, pedaling in urban areas could be positively associated with the chance of a bicycle accident, whereas higher level of education and the use of the bicycle as a commute had an inverse association?

However, these data were obtained through information systems such as VIVA, and despite their relevance, they exhibit some limitations. Victims of minor seriousness accidents usually do not seek care in health services, and therefore are not included in the statistics, resulting in an underestimated data ${ }^{8}$. Yet, despite characterizing the victims, these data do not allow identifying the risk factors for the incidence of accidents, limiting the creation of effective public policies to control and to prevent aggravation. Therefore evaluating these accidents and minor gravity events may help to generate a better understanding of accidents that involve the use of the bicycle. In this regard, events of lesser gravity such as falls and small collisions or the ones that are closely related to accidents, such as braking and abrupt changing of direction are defined as critical events?

Thus, to investigate characteristics, beyond those that the information systems are able to produce, and critical events one of the alternatives found was to conduct investigations at the time and place where the events occur. This can be accomplished through the use of portable cameras attached to the cyclist helmet, which through its record allows the details of the critical event $^{6,10,11}$ to be seen and recovered after its occurrence ${ }^{6,12}$. One of the studies conducted with this approach identified that the risk of suffering a critical event was ten times higher when the surface of the pathways were considered poorly maintained ${ }^{11}$. Also, a fourfold higher risk was observed in the proximity of intersections, being it threefold higher in intersection with visual occlusion and when pedestrians and other cyclists crossed the cyclist's trajectory ${ }^{11}$.

Thereby, in order to be able to identify which behavioral characteristics of cyclists and environmental variables may be associated with critical events, it is essential to have instruments that allow the registration of 
these variables with adequate reproducibility. Therefore, the objective of this study was to develop and test the reproducibility of an instrument to evaluate behavioral and environmental aspects related to the safety of cyclists on public roads.

\section{METHOD}

A reproducibility study with cross-sectional design was carried out. The steps of development and reproducibility analysis of the instrument were adopted.

\section{Development of the instrument}

The instrument was developed to describe information during bicycle trips taken by university students, which would allow the evaluation of variables potentially associated with critical events.

The items that were included in the form were selected according to the literature on the topic and previously recorded videos (pilot study). According to the literature review ${ }^{12}$ variables such as demographic factors, built environment, climate conditions, street lighting and behavioral conditions should be considered when evaluating the safety of the cyclist. Thus, based on the factors cited in the literature, an observer familiarized with the use of the bicycle for transportation ${ }^{6}$ developed a registration form founded on the variables indicated by the literature review and on the pilot study videos. Those were taken through camera positioned on the helmet of 28 cyclists during the period of seven days. From these images the characteristics that could be visualized integrated the instrument.

The instrument was tested in a sample of periods taken from the pilot study by two evaluators familiarized with the use of the bicycle for transportation. The final version of the instrument was established through the consensus of the evaluators who participated in the data collection. Box 1 presents the instrument variables, divided into three sections.

Among the categorical variables, the instrument shows different possibilities of the quantity of responses. Five variables are dichotomous, "crossing lane", "presence of mandatory stop sign", "presence of preferential sign", "presence of traffic lights" and "There is no traffic control". The variables "observer temperature perception", "running the red light", "pedaling in the wrong way", "zigzag between vehicles", "using pedestrian-only sidewalk", "own infrastructure available and used" and "parked vehicles" exhibit as an option more than two responses with possibility of a single result, and the other variables have more than two responses options with multiple results. The multiple response procedure was used to record the different situations occurring within the 30 seconds range.

\section{Sampling of cyclists}

Four universities located in the city of Curitiba-PR were intentionally selected for the sample of cyclists' recruitment. The recruitment took place at the bike racks installed at the universities' outbuilding. All individuals 
who would go to the parking rack area in order to park or take a bicycle were approached. The inclusion criteria were: a) being a university student at one of the four universities; b) minimum age of 18 years; c) using the bicycle for transportation at least once a week and d) taking routes at least 5 minutes long.

Box 1. Structure of the instrument

\begin{tabular}{|c|c|c|c|}
\hline Section & Variable name & Variable type & Response type \\
\hline \multirow{6}{*}{$\begin{array}{l}\text { Route identifi- } \\
\text { cation }\end{array}$} & Date of route & Nominal & - \\
\hline & Time of the day & Nominal & - \\
\hline & Video period & Nominal & - \\
\hline & Day of the week & Nominal & - \\
\hline & Max./min. temperature & Continuous & Numerical \\
\hline & Perception of observer temperature & Categorical & Single answer \\
\hline \multirow{8}{*}{ Behavioral } & Location of the cyclist on the road & Categorical & Multiple answer \\
\hline & Cyclist's direction & Categorical & Multiple answer \\
\hline & Crossing track & Categorical & Dichotomous \\
\hline & Run the red light & Categorical & Single answer \\
\hline & Pedaling the wrong way & Categorical & Single answer \\
\hline & Perform zigzag between vehicles & Categorical & Single answer \\
\hline & Pedaling on the pedestrians sidewalk & Categorical & Single answer \\
\hline & Own infrastructure available and used & Categorical & Single answer \\
\hline \multirow{11}{*}{ Environmental } & Location of the road used & Categorical & Multiple answer \\
\hline & Type of bicycle infrastructure & Categorical & Multiple answer \\
\hline & Presence of parked vehicles & Categorical & Single answer \\
\hline & Mandatory stop & Categorical & Dichotomous \\
\hline & Preferential & Categorical & Dichotomous \\
\hline & Traffic light for vehicles & Categorical & Dichotomous \\
\hline & There is no traffic control & Categorical & Dichotomous \\
\hline & Perception of observer topography & Categorical & Multiple answer \\
\hline & Number of vehicles & Continuous & Numerical \\
\hline & Number of pedestrians & Continuous & Numerical \\
\hline & Number of cyclists & Continuous & Numerical \\
\hline
\end{tabular}

\section{Data collection procedures}

In order to record the videos, was given to the participant a portable camera, the used brand was GoPro ${ }^{\circledR}$ (San Mateo, United States) in the following available models: "Hero3 + Silver Edition", "Hero4 Silver Edition" and "Hero4 Black Edition". Following the cameras was an acrylic protective box which allows the equipment attachment to the helmet surfaces through brackets. The cameras were fixed on the highest point of the helmet by the researcher. Helmets with supports were lent to participants who did not have it or whose helmet did not allow the camera to be fixed. The cameras were set to shoot at a rate of 30 frames per second (30fps) at a resolution of $720 \mathrm{p}$ ("p" indicates the "progressive" picture format). Figure 1 shows an image obtained during data collection. 


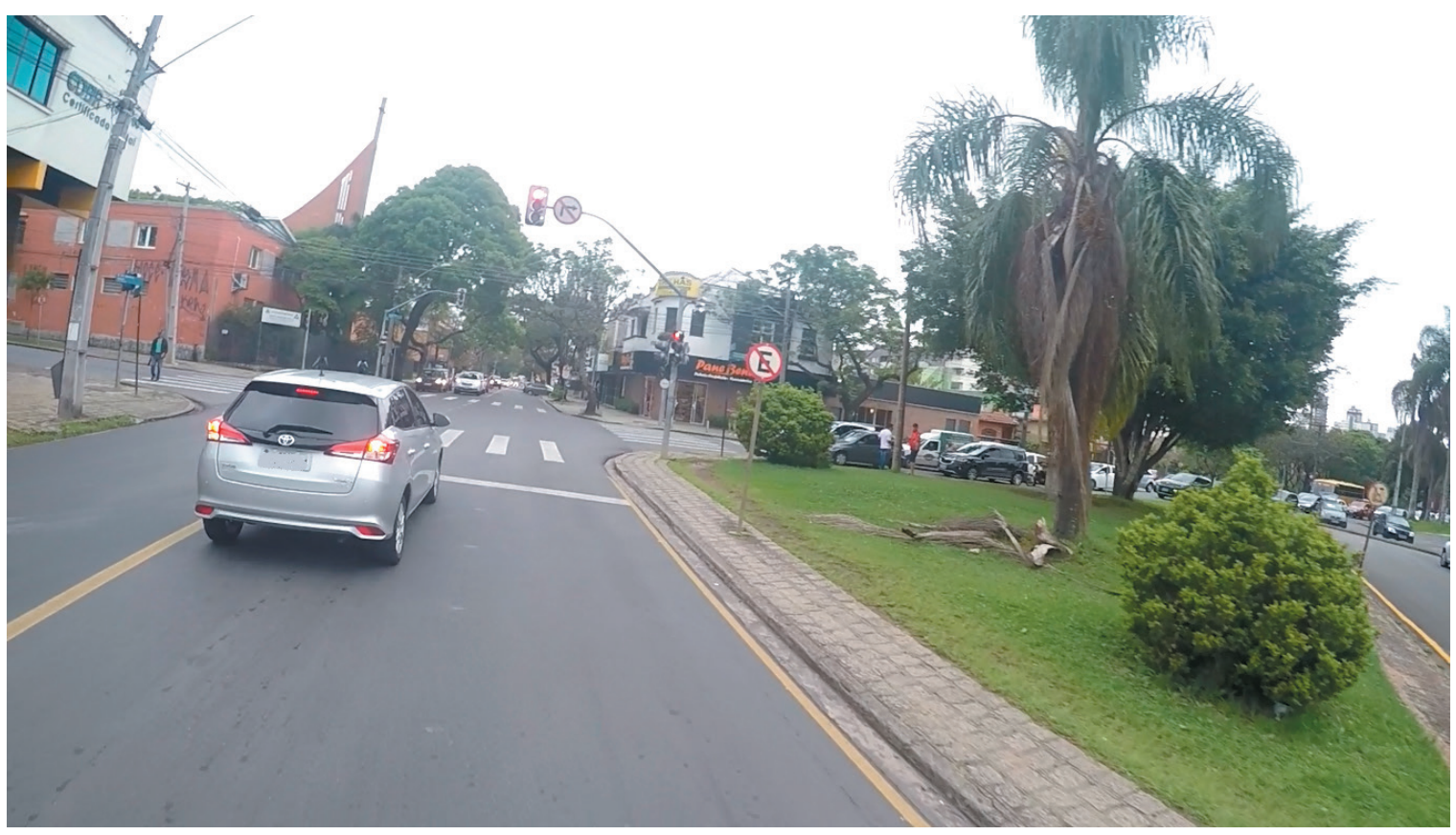

Figure 1. Example of footage taken through the recording of the cyclist participant on the route.

For each taken route, the participant was requested to keep a route diary to record details of the trip (date, time of day, origin and destination, use of headset) and indicate any critical event, being this defined as a situation based on the perception of insecurity or discomfort in relation to traffic during travel. The participants were instructed to record all the routes made during seven consecutive days.

Altogether, 76 critical events were indicated. Of these, 54 (71.1\%) were considered valid and occurred over 34 routes. These routes were divided in period of 30 seconds and were classified as eligible and ineligible. It was considered ineligible the period in which the cyclist: 1) was on private ground, 2) was off the bicycle or pushing it or 3) it was not possible to visualize the variables of interest (for example: poor lighting).

In order to achieve concordance, a sample of 100 periods was chosen. First, all the periods with critical events were selected. Afterwards, a systematic draw was carried out among the eligible periods of 30 seconds without the presence of critical events. For each critical event identified in the previous step, a sample of five periods from the same route was drawn. The periods were drawn dividing the total number of valid periods without the presence of critical events by the total number of periods that would be used in the route. The result was used as a "leap" from the first period.

\section{Video data training and collecting}

In order to perform the inter-rater agreement, two evaluators (A and B) received six-hour theoretical-practical training. Concerning the identification of the factors, the procedure of splitting the routes in period of 30 seconds was adopted, a process also used in a study with similar subject matter ${ }^{11}$. There 
after each evaluator observed 100 samples of periods independently, and, when needed, there was a possibility of reviewing the records individually and without previous communication with the other evaluators. Purposing to perform the intra-rater agreement, the volunteer A carry out the data collection in two distinct moments, using a time gap of 7 days between the evaluations.

\section{Statistical analysis}

For the categorical variables of the instrument, the relative frequency of observations per evaluator was calculated in each category of variables. The reliability between evaluators and intra-evaluators was tested by general agreement $(\% \mathrm{C})$ and kappa index $(\mathrm{K})$ per variable category. Regarding the dichotomous categorical variables, the values were calculated per variable. Relating to the continuous variables, mean and standard deviation of each variable were calculated and the reliability was tested through the intraclass correlation coefficient (IC) and 95\% confidence interval. Values of general agreement $\geq 70.0 \%$, kappa index $\geq 0.70$ and intraclass correlation coefficient $\geq 0.70$ were considered suitable reproducibility values ${ }^{13}$. The analyzes were performed in SPSS (Armonk, United States) 20.0 software and the significance level adopted was $5 \%$.

\section{RESULTS}

Among the dichotomous variables, there was a high inter-general (97.0 - 99.0\%) and intra-rater (95.0 - 97.0\%) agreement observed. Values of the kappa index revealed concordances higher than 0.80 . The intra-rater "there is no traffic control" variable had the lowest kappa value (0.869) among these variables (table 1).

Table 1. Frequency distribution, general agreement $(\% \mathrm{C})$ and Kappa $(\mathrm{K})$ index inter and intra-rater of dichotomous variables of the instrument

\begin{tabular}{|c|c|c|c|c|c|c|c|c|c|c|}
\hline & $\mathrm{A} 1$ & B & $\% \mathrm{C}$ & K & $\mathrm{p}$ & A1 & A2 & $\% \mathrm{C}$ & K & $p$ \\
\hline Variables and categories & $\%$ & $\%$ & & & & $\%$ & $\%$ & & & \\
\hline \multicolumn{11}{|l|}{ Crossing track } \\
\hline Yes & 64 & 63 & 97.0 & 0.935 & $<0.001$ & 64 & 64 & 96.0 & 0.913 & $<0.001$ \\
\hline Not & 36 & 37 & & & & 36 & 36 & & & \\
\hline \multicolumn{11}{|c|}{ "mandatory stop" traffic control } \\
\hline Yes & 29 & 29 & 98.0 & 0.951 & $<0.001$ & 29 & 25 & 96.0 & 0.899 & $<0.001$ \\
\hline Not & 71 & 71 & & & & 71 & 75 & & & \\
\hline \multicolumn{11}{|c|}{ "Preferential" traffic control } \\
\hline Yes & 0 & 0 & 100 & - & - & 0 & 0 & 100 & - & - \\
\hline Not & 100 & 100 & & & & 100 & 100 & & & \\
\hline \multicolumn{11}{|c|}{ "traffic light for vehicles" traffic control } \\
\hline Yes & 53 & 52 & 99.0 & 0.980 & $<0.001$ & 53 & 47 & 97.0 & 0.940 & $<0.001$ \\
\hline Not & 47 & 48 & & & & 47 & 50 & & & \\
\hline \multicolumn{11}{|l|}{ There is no traffic control } \\
\hline Yes & 77 & 76 & 99.0 & 0.972 & $<0.001$ & 77 & 72 & 95.0 & 0.869 & $<0.001$ \\
\hline Not & 23 & 24 & & & & 23 & 28 & & & \\
\hline
\end{tabular}

Note. A1\%: frequency of observations evaluator $A 1 ; B \%$ : frequency of observations evaluator $B ; A 2 \%$ : frequency of observations evaluator A2; \% C: general agreement; K: Kappa index, p: level of significance; it was not possible to calculate concordance values in the variable "preferential traffic control" because the categories were constant. 
Overall agreement values for single response variables were similarly high inter (94.0 - 100.0\%) and intra-rater (88.0 - 97.0\%). All variables had kappa index values higher than 0.80 , and the "own and available infrastructure" variable presented perfect agreement (table 2).

Table 2. Frequency distribution, general agreement $(\% \mathrm{C})$ and Kappa $(\mathrm{K})$ index inter and intra-rater of single answer variables of the instrument

\begin{tabular}{|c|c|c|c|c|c|c|c|c|c|c|}
\hline & A1 & B & $\% \mathrm{C}$ & K & $p$ & $\mathrm{~A} 1$ & A2 & $\% \mathrm{C}$ & K & $p$ \\
\hline Variables and categories & $\%$ & $\%$ & & & & $\%$ & $\%$ & & & \\
\hline \multicolumn{11}{|l|}{ Perception of observer temperature } \\
\hline Sun between the clouds & 50 & 47 & 97.0 & 0.940 & $<0.001$ & 50 & 47 & 95.0 & 0.900 & $<0.001$ \\
\hline Cloudy & 50 & 53 & & & & 50 & 53 & & & \\
\hline \multicolumn{11}{|l|}{ Running the red light } \\
\hline Yes & 10 & 10 & 94.0 & 0.897 & $<0.001$ & 10 & 10 & 91.0 & 0.843 & $<0.001$ \\
\hline Not & 40 & 42 & & & & 40 & 35 & & & \\
\hline There is no traffic light & 50 & 48 & & & & 50 & 55 & & & \\
\hline \multicolumn{11}{|l|}{ Pedaling the wrong way } \\
\hline Yes & 19 & 18 & 96.0 & 0.936 & $<0.001$ & 19 & 19 & 96.0 & 0.937 & $<0.001$ \\
\hline Not & 47 & 47 & & & & 47 & 43 & & & \\
\hline Did not pedal on the track & 34 & 35 & & & & 34 & 38 & & & \\
\hline \multicolumn{11}{|l|}{ Perform zigzag between vehicles } \\
\hline Yes & 0 & 0 & 97.0 & 0.934 & $<0.001$ & 0 & 1 & 95.0 & 0.893 & $<0.001$ \\
\hline Not & 66 & 65 & & & & 66 & 61 & & & \\
\hline Did not pedal on the track & 34 & 35 & & & & 34 & 38 & & & \\
\hline \multicolumn{11}{|l|}{ Pedaling on the pedestrians sidewalk } \\
\hline Yes & 22 & 23 & 96.0 & 0.928 & $<0.001$ & 22 & 20 & 94.0 & 0.890 & $<0.001$ \\
\hline Not & 61 & 59 & & & & 61 & 62 & & & \\
\hline There is no sidewalk & 17 & 18 & & & & 17 & 18 & & & \\
\hline \multicolumn{11}{|l|}{ Own infrastructure available and used } \\
\hline Yes & 40 & 40 & 100.0 & 1.000 & $<0.001$ & 40 & 41 & 97.0 & 0.939 & $<0.001$ \\
\hline Not & 1 & 1 & & & & 1 & 0 & & & \\
\hline There is no own infrastructure & 59 & 59 & & & & 59 & 59 & & & \\
\hline \multicolumn{11}{|l|}{ Parked vehicles } \\
\hline From both sides of the road & 15 & 16 & 98.0 & 0.971 & $<0.001$ & 15 & 13 & 88.0 & 0.823 & $<0.001$ \\
\hline On the same side as the cyclist & 20 & 20 & & & & 20 & 14 & & & \\
\hline On the opposite side of the cyclist & 19 & 20 & & & & 19 & 22 & & & \\
\hline There are no parked vehicles & 46 & 44 & & & & 46 & 51 & & & \\
\hline
\end{tabular}

$A 1 \%$ : frequency of observations evaluator $A 1 ; B \%$ : frequency of observations evaluator $B ; A 2 \%$ : frequency of observations evaluator A2; \% C: general agreement; k: kappa index and p: significance level

For the variables with the possibility of multiple answers, the concordance values were presented per category of variable. Among all categories, the overall agreement results were higher than $90.0 \%$ inter and intra-rater. Among the kappa index values, the categories showed values greater than 0.80 , except the categories "lateral lane on the left" and "flat surface" considering the inter-rater analysis and "pedaling ahead" considering the intra-rater analysis (table 3). Finally, all continuous variables presented intraclass correlation values higher than 0.90 (table 4). 
Table 3. Frequency distribution, general agreement (\% C) and Kappa (K) index inter and intra-rater of multiple answers variables of the instrument

\begin{tabular}{|c|c|c|c|c|c|c|c|c|c|c|}
\hline & A1 & B & $\% \mathrm{C}$ & K & $p$ & A1 & A2 & $\% \mathrm{C}$ & K & $p$ \\
\hline Variables and categories & $\%$ & $\%$ & & & & $\%$ & $\%$ & & & \\
\hline \multicolumn{11}{|l|}{ Location of the cyclist on the road } \\
\hline Right side of lane & 23 & 25 & 98.0 & 0.945 & $<0.001$ & 23 & 25 & 96.0 & 0.890 & $<0.001$ \\
\hline Left side of lane & 11 & 11 & 96.0 & 0.796 & $<0.001$ & 11 & 10 & 97.0 & 0.840 & $<0.001$ \\
\hline In the middle of the lane & 22 & 21 & 99.0 & 0.970 & $<0.001$ & 22 & 22 & 96.0 & 0.883 & $<0.001$ \\
\hline Shoreline & 0 & 0 & - & - & - & 0 & 0 & - & - & - \\
\hline Sidewalk & 21 & 22 & 99.0 & 0.970 & $<0.001$ & 21 & 19 & 98.0 & 0.938 & $<0.001$ \\
\hline Own infrastructure & 41 & 40 & 99.0 & 0.979 & $<0.001$ & 41 & 42 & 99.0 & 0.979 & $<0.001$ \\
\hline \multicolumn{11}{|l|}{ Cyclist's direction } \\
\hline Pedaling ahead & 98 & 98 & 100.0 & 1.000 & $<0.001$ & 98 & 97 & 99.0 & 0.795 & $<0.001$ \\
\hline Turning right & 6 & 8 & 98.0 & 0.847 & $<0.001$ & 6 & 5 & 99.0 & 0.904 & $<0.001$ \\
\hline Turning left & 5 & 4 & 99.0 & 0.884 & $<0.001$ & 5 & 5 & 100.0 & 1.000 & $<0.001$ \\
\hline Stopped & 21 & 20 & 95.0 & 0.847 & $<0.001$ & 21 & 23 & 96.0 & 0.884 & $<0.001$ \\
\hline \multicolumn{11}{|l|}{ Location of the road used } \\
\hline Track & 37 & 37 & 98.0 & 0.957 & $<0.001$ & 37 & 39 & 96.0 & 0.915 & $<0.001$ \\
\hline BRT (Bus Corridors) & 13 & 12 & 99.0 & 0.954 & $<0.001$ & 13 & 11 & 98.0 & 0.905 & $<0.001$ \\
\hline Shoreline & 0 & 0 & - & - & - & 0 & 0 & - & - & - \\
\hline Sidewalk & 21 & 22 & 99.0 & 0.970 & $<0.001$ & 21 & 19 & 98.0 & 0.938 & $<0.001$ \\
\hline Own infrastructure & 40 & 40 & 100.0 & 1.000 & $<0.001$ & 40 & 42 & 98.0 & 0.959 & $<0.001$ \\
\hline \multicolumn{11}{|l|}{ Type of own infrastructure } \\
\hline Bicycle path & 12 & 12 & 100.0 & 1.000 & $<0.001$ & 12 & 13 & 99.0 & 0.954 & $<0.001$ \\
\hline Cycle Track & 3 & 4 & 99.0 & 0.852 & $<0.001$ & 3 & 3 & 100.0 & 1.000 & $<0.001$ \\
\hline Calm way (low speed limit streets) & 11 & 10 & 99.0 & 0.947 & $<0.001$ & 11 & 12 & 99.1 & 0.951 & $<0.001$ \\
\hline Shared sidewalk & 14 & 14 & 100.0 & 1.000 & $<0.001$ & 14 & 14 & 98.0 & 0.917 & $<0.001$ \\
\hline Cycle route & 0 & 0 & - & - & - & 0 & 0 & - & - & - \\
\hline Available and unused own infrastructure & 1 & 1 & 100.0 & 1.000 & $<0.001$ & 1 & 0 & 99.0 & & \\
\hline There is no own infrastructure & 59 & 59 & 100.0 & 1.000 & $<0.001$ & 59 & 58 & 99.0 & 0.979 & $<0.001$ \\
\hline \multicolumn{11}{|l|}{ Perception of observer topography } \\
\hline Aclive & 28 & 25 & 93.0 & 0.821 & $<0.001$ & 28 & 33 & 95.0 & 0.882 & $<0.001$ \\
\hline Plan Surface & 62 & 67 & 89.0 & 0.760 & $<0.001$ & 62 & 63 & 91.0 & 0.808 & $<0.001$ \\
\hline Slope & 20 & 18 & 96.0 & 0.870 & $<0.001$ & 20 & 15 & 85.0 & 0.828 & $<0.001$ \\
\hline
\end{tabular}

Note. $A 1 \%$ : frequency of observations evaluator $A 1 ; B \%$ : frequency of observations evaluator $B ; A 2 \%$ : frequency of observations evaluator A2; \% C: general agreement; $\mathrm{k}$ : kappa index and p: significance level; it was not possible to calculate concordance values in the categories "coasting", "ciclorrota" and "own available and unused infrastructure" (intra raters) because the categories were constant.

Table 4. Mean, standard deviation and inter and intra-rater intraclass correlation coefficient of the continuous variables of the instrument

\begin{tabular}{|c|c|c|c|c|c|c|c|c|}
\hline & \multicolumn{4}{|c|}{ Inter-raters } & \multicolumn{4}{|c|}{ Intra-rater } \\
\hline \multirow{2}{*}{ Variables } & $\mathrm{A} 1$ & B & & & A1 & A2 & & \\
\hline & $\mathrm{M} \pm \mathrm{DP}$ & $\mathrm{M} \pm \mathrm{DP}$ & $\mathrm{CCl}\left(\mathrm{IC}_{95 \%}\right)$ & $p$ & $\mathrm{M} \pm \mathrm{DP}$ & $\mathrm{M} \pm \mathrm{DP}$ & $\mathrm{CCl}\left(\mathrm{IC}_{95 \%}\right)$ & $p$ \\
\hline \# vehicles & $12.8 \pm 10.3$ & $13.5 \pm 10.5$ & $0.989(0.983-0.992)$ & $<0.001$ & $12.8 \pm 10.3$ & $12.2 \pm 9.7$ & $0.961(0.942-0.974)$ & $<0.001$ \\
\hline \# pedestrians & $8.1 \pm 19.5$ & $8.5 \pm 20.8$ & $0.997(0.996-0.998)$ & $<0.001$ & $8.1 \pm 19.5$ & $8.3 \pm 19.0$ & $0.996(0.995-0.998)$ & $<0.001$ \\
\hline \# cyclists & $0.3 \pm 0.6$ & $0.3 \pm 0.6$ & $0.960(0.940-0.973)$ & $<0.001$ & $0.3 \pm 0.6$ & $0.3 \pm 0.6$ & $0.988(0.981-0.992)$ & $<0.001$ \\
\hline
\end{tabular}

Note. \#: number of observations; M: mean; SD: standard deviation; ICC: intraclass correlation coefficient; IC $95 \%$ : $95 \%$ confidence interval and $\mathrm{p}$ : significance value 


\section{DISCUSSION}

The present study was the first one in Brazil to develop a specific instrument to determine aspects related to the safety of universities cyclists when traveling on public roads. Behavioral and environmental aspects observed through cameras fixed to the cyclist's helmet were observed. The instrument presented adequate reproducibility values.

Overall intra and inter-rater concordance percentages were elevated for all categorical variables (88.0 - 100.0\%), in the same way kappa index presented values of high coefficients $(0.760-1.000)$. Among the continuous variables, we observed equally high values of intraclass correlation coefficient $(0.960$ - 0.997). In a previous study that aimed to identify the type and characteristics of critical events between cyclists and drivers, it was observed that the lowest inter-rater concordance values were adequate and similar to those of the present study (0,667 and 0.769, respectively).

The lowest concordance values were observed in three categories of multi-response variables, being them the "left side of the lane" and "flat surface" when considering the inter-rater analysis and "pedaling ahead" when considering the intra-rater analysis. This may have happened due to the possibility of indicating more than one response option, which, although it allows the identification of particularities, may require better established protocols and a more refined training with the evaluators, in order to avoid observation nuances gathering.

Until this moment, an instrument that allows a more detailed evaluation of the characteristics of these accidents has not been found in the literature. This study represents a contribution in the area of control and prevention of bicycle accidents on public roads, since the information obtained through this instrument would be able to help the targeting of public policies focused on this subject. The development of the instrument followed recommended steps ${ }^{13}$ and evaluated separately each component of the instrument, which made it possible to identify in details the quality of each item of the instrument.

However, some limitations must be considered in order to extrapolate the results. The instrument evaluates samples of a 30 seconds range route, which may not represent the different situations along the trip. In addition, the instrument was developed through trips made in the city of Curitiba, and adaptations may be necessary when applied in different cities. Some conditions may complicate the variables collect of interest, such as rainy days or periods of the day without natural light, limiting the results of this study to exceed other periods and in different climatic conditions.

\section{CONCLUSION}

The developed instrument showed adequate reproducibility to determine behavioral and environmental aspects in public roads. 


\section{COMPLIANCE WITH ETHICAL STANDARDS}

\section{Funding}

This research did not receive any specific grant from funding agencies in the public, commercial, or not-for-profit sectors. This study was funded by the authors.

\section{Ethical approval}

Ethical approval was obtained from the Human Research Ethics Committee of the Pontifical Catholic University of Paraná, and the protocol was written according to the standards established by the Declaration of Helsinki.

\section{Conflict of interest statement}

The authors have no conflict of interests to declare.

\section{Author Contributions}

Elaboration and design of the experiment: $\mathrm{TC}$ and $\mathrm{AH}$. Experiments: $\mathrm{CT}$ and IC. Data analysis: CT and AH. Article Writing: TC, IC and AH. All authors read and approved the final version of the manuscript.

\section{REFERENCES}

1. Caixeta CR, Minamisava R, Oliveira LM de AC, Brazil VV. Morbidity due to transportation accidents among young people from Goiânia, Goiás. Cien Saude Colet 2009; 14 (5): 1807-15.

2. Costa JSD da, Victora CG. What is a public health problem? Rev Bras Epidemiol 2006; 9 (1): 144-51.

3. Ministries of Health. Datasus [Internet]. Available from: http://tabnet.datasus. gov.br/cgi/tabcgi.exe?sim/cnv/ext10uf.def

4. Ministry of Health. VIVA: Vigilance of Violence and Accidents: 2013 and 2014. 2017.

5. Rodrigues CL, Armond JDE, Gorios C, Souza PC. Accidents involving motorcyclists and cyclists in the city of São Paulo: characterization and trends. Rev Bras Ortop 2014; 49 (6): 602-6.

6. Johnson M, Charlton J, Oxley J, Newstead S. Naturalistic cycling study: identifying risk factors for on-road commuter cyclists. Ann Adv Automot Med 2010; 54: 275-83.

7. Sousa CAM, Bahia CA, Constantino P. Analysis of factors associated with traffic accidents involving cyclists attended in Brazilian capitals. Cien Saude Colet 2016; 21 (12): 3683-90.

8. Barros AJD, Amaral RL, Oliveira MSB, Lima SC, Gonçalves E V. Traffic accidents with victims: underregistration, characterization and lethality. Cad Saude Publica 2003; 19 (4): 979-86.

9. Bacchieri G, Barros AJD, Santos JV dos, Gonçalves H, Giant DP. Community intervention to prevent traffic accidents among cyclists. Rev Saude Publica 2010; 44 (5): 867-75.

10. Hamann CJ, Peek-Asa C. Examination of adult and child bicyclist safety-relevant events using naturalistic bicycling methodology. Accid Anal Prev 2017; 102: 1-11.

11. Dozza M, Werneke J. Introducing naturalistic cycling data: What factors influence bicyclists' safety in the real world? Transp Res Part of Traffic Psychol Behav 2014; 24: 83-91. 
12. Vanparijs J, Int Panis L, Meeusen R, De Geus B. Exposure measurement in bicycle safety analysis: A review of the literature. Accid Anal Prev 2015; 84: 9-19.

13. Terwee CB, Bot SDM, Boer MR, van der Windt DAWM, Knol DL, Dekker J, et al. Quality criteria were proposed for measurement properties of health status questionnaires. J Clin Epidemiol 2007; 60: 34-42.

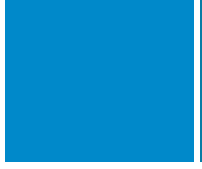

Corresponding author

Talita Chrystoval Truchym

Pedro Gusso street, 2601 - Novo Mundo, Curitiba - PR, Brazil.

Zip postal: 81310-900

E-mail: truchym.talita@gmail.com 